\title{
INTERPRETATION OF CHANGES IN THE ASH CONTENT OF OMBROTROPHIC PEAT LAYERS
}

\author{
KIMMO TOLONEN
}

\begin{abstract}
TOLONEN, K., 1984: Interpretation of changes in the ash content of ombrotrophic peat layers. Bull. Geol. Soc. Finland 56, Part 1-2, 207-219.

The spatial and temporal variation of ash content in ombrotrophic Sphagnum peat and its relation to the history of land use has been examined in the light of several pollen diagrams and different physical and chemical analyses from dated peat cores (in thirteen mires in Finland and one in northern Norway).

The ash content of Sphagnum peat often correlates with the quantity of windblown mineral particles from fields and other bare soils. Reconstruction of the history of field erosion was complicated or even made impossible by the involved movements of elements.
\end{abstract}

Key words: Sphagnum peat, field erosion, wind-blown dust, recycling of elements, primary ash

K. Tolonen: Department of Botany, University of Helsinki, Unioninkatu 44, SF-00170 Helsinki 17, Finland.

\section{Introduction}

The ash content of ombrotrophic peat, which forms the uppermost deposits in raised bogs (Hochmoore), is generally low. This is because its parent vegetation does not receive extra mineral nutrients from minerogenic waters, but lives off the nutrient store of the peat itself besides what falls from the air.

The geochemistry of raised bogs has become an important subject of study, especially since the works of C.A. Weber and his contemporaries in Germany. The results of countless ash content analyses of ombrotrophic peat have been published and examined in several countries and from various points of view. The topics discussed include 1) the geochemical indication of the $\gg$ paleohydrological mineral soil water boundary» (= fen/bog limit) (e.g.
Schneekloth 1963, Chapman 1964, Tolonen 1966, 1967, Mörnsjö 1968, Tallis 1973), 2) the usability of peat and surface vegetation in prospecting for bog-covered ore (see e.g. Salmi 1955, 1967 with references, Yliruokanen 1976), 3 ) the accumulation and movements of elements including trace metals in peat (e.g. Damman 1978, Pakarinen et al. 1981 with references), 4) the role of airborne agrarian dust (e.g. v. Post 1925, Mattson and Koutler-Andersson, 1954, Chapman 1964, Mörnsjö 1968, Gorham \& Tilton 1978, Sillanpää 1972, Vuorela 1983) and industrial pollutants (e.g. Oldfield et al. 1981, Pakarinen et al. 1983 with references), 5) the significance of ash content for the energy yield of peat (e.g. Salmi 1947, 1954, Lappalainen 1970) and as an explanation of the bulk density of peat (e.g. Päivänen 1969, 1973, Tolonen \& Saarenmaa 1979), and 6) the variation in the 
primary ash content of mire plants and surface peats (e.g. Malmer \& Sjörs 1955, Sylvester \& Wein 1971).

Numerous highly relevant studies dealing with ash in ombrotrophic peats have also been published in the sector of forestry, horticultural and agrarian utilization of peat and peatlands.

The aim of this paper is to evaluate the significance of the spatial and temporal patterns in the ash content of ombrotrophic peat in different parts of Finland in the light of peat geological analyses from dated peat profiles. Special attention is focused on the circumstances in which the ash content curves of Sphagnum peat profiles are a valid indicator of field erosion by wind, as recently implied by Vuorela (1983).

\section{Material and methods}

The material is from eleven raised bogs and two palsa mires in Finland and one palsa mire in Norwegian Lapland sampled in 1976-1983. Almost all the peat cores were taken using a very sharp, thin-walled steel cylinder $(64 \times 12$ $\mathrm{cm}$ ) and a big Russian peat sampler (Tolonen \& Ijäs 1982) from Sphagnum fuscum hummocks containing as few vascular plants as possible.
1
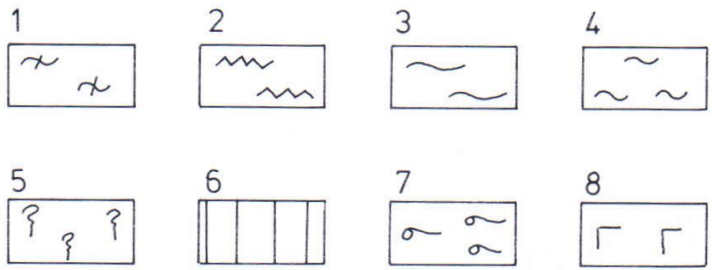

9
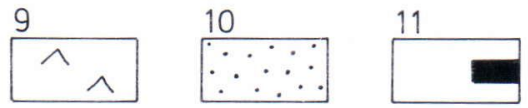

Fig. 1. Key of symbols. $1=$ Sphagnum fuscum, $2=\mathrm{S}$. magellanicum, $3=\mathrm{S}$. sect. cuspidata, $4=$ Sphagnum, collectively, $5=$ Eriophorum vaginatum, $6=$ Carex, $7=$ Bryales, 8 = Equisetum, $9=$ wood, $10=$ sand, $11=$ sample for radiocarbon dating.

The samples were taken chiefly for geochemical analyses of heavy metals and paleomagnetic properties, they were therefore carefully wrapped in plastic in the field. The carbon content of the peat (in some profiles) was analysed as $\mathrm{CO}_{2}$ by the infrared method at Lammi Biological Station (Salonen 1979).

The oven-dry $\left(+60^{\circ} \mathrm{C}\right)$ peat samples were milled, dried again and ignited for at least $4 \mathrm{~h}$ at $550^{\circ} \mathrm{C}$. The amount of dry material in the analyses varied from 1 to $3 \mathrm{~g}$.

In several short cores dating was done by the moss increment method (Pakarinen \& Tolonen

Table 1. Locations of the peatlands studied and the distance of the coring sites from the nearest arable land (Dist. A) and permanently used roads (Dist. B) in $\mathrm{km}$.

\begin{tabular}{|c|c|c|c|}
\hline Name of bog, parish & Location & Dist. A & Dist. B \\
\hline Kevolansuo, Paimio & $60^{\circ} 26^{\prime} \mathrm{N}, 22^{\circ} 46^{\prime} \mathrm{E}$ & 0.8 & 0.8 \\
\hline Punassuo, Perniö & $60^{\circ} 13^{\prime} \mathrm{N}, 23^{\circ} 02^{\prime} \mathrm{E}$ & 1.2 & 0.7 \\
\hline Munasuo, Pyhtää & $60^{\circ} 34^{\prime} \mathrm{N}, 26^{\circ} 40^{\prime} \mathrm{E}$ & 2.0 & 2.5 \\
\hline Laaviosuo, Lammi & $61^{\circ} 01^{\prime} \mathrm{N}, 25^{\circ} 00^{\prime} \mathrm{E}$ & 1.1 & 1.2 \\
\hline Kärpänsuo, Kuhmoinen & $61^{\circ} 38^{\prime} \mathrm{N}, 25^{\circ} 22^{\prime} \mathrm{E}$ & 0.2 & 1.1 \\
\hline Kunonniemensuo, Kitee & $62^{\circ} 06^{\prime} \mathrm{N}, 30^{\circ} 13^{\prime} \mathrm{E}$ & 2.0 & 1.5 \\
\hline Linnasuo, Tuupovaara & $62^{\circ} 32^{\prime} \mathrm{N}, 30^{\circ} 23^{\prime} \mathrm{E}$ & 0.7 & 1.0 \\
\hline Liikasenvaaran suo, Kuusamo & $66^{\circ} 22^{\prime} \mathrm{N}, 29^{\circ} 30^{\prime} \mathrm{E}$ & 0.5 & 0.6 \\
\hline Jänkävuopajanaapa, Sodankylä & $67^{\circ} 23^{\prime} \mathrm{N}, 26^{\circ} 43^{\prime} \mathrm{E}$ & 3.0 & 3.5 \\
\hline Ahvenjärvenvuoma, Kittilä & $67^{\circ} 37^{\prime} \mathrm{N}, 25^{\circ} 16^{\prime} \mathrm{E}$ & 1.0 & 0.3 \\
\hline Ahmajänkä, Inari & $69^{\circ} 12^{\prime} \mathrm{N}, 27^{\circ} 10^{\prime} \mathrm{E}$ & ca. 3 & 0.3 \\
\hline Skallovarrin palsasuo, Utsjoki & $69^{\circ} 5^{\prime} \mathrm{N}, \quad 27^{\circ} 12^{\prime} \mathrm{E}$ & ca. 8 & ca. 6 \\
\hline Peerajärven palsasuo, Enontekiö & $68^{\circ} 53^{\prime} \mathrm{N}, 21^{\circ} 02^{\prime} \mathrm{E}$ & ca. 9 & 0.4 \\
\hline Palsasuo Vuoddasjavri, N. Norway & $69^{\circ} 22^{\prime} \mathrm{N}, 24^{\circ} 01^{\prime} \mathrm{E}$ & ca. 20 & 0.4 \\
\hline
\end{tabular}




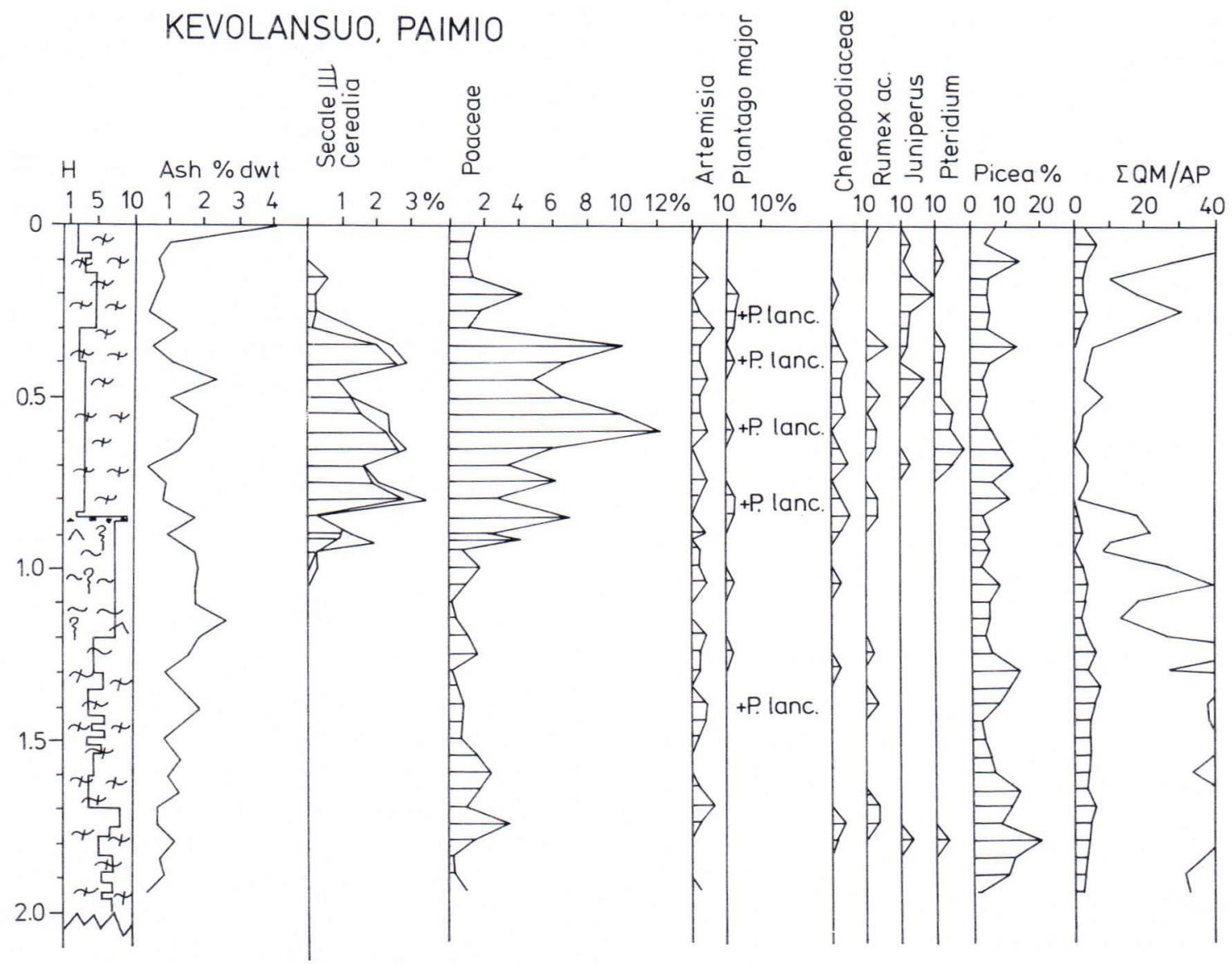

Fig. 2. Raised bog Kevolansuo, Paimio, 1983. Ash content of peat compared with selected indicators of cultivation as occurring in pollen analyses from the same samples. The sum of AP counted is 500.

The humification of peat is indicated in the peat type column by v. Post's 10-grade scale (Hl-10). Explanations in Fig. 1. Source: Mirjami Tolonen's unpubl. data.

1977) and in three cores by the ${ }^{210} \mathrm{~Pb}$ method applying the c.r.s. model (see El-Daoushy et al. 1982). These isotope determinations were carried out jointly by the Reactor Laboratory of the Technical Research Centre of Finland and the Department of Physics, University of Uppsala, Sweden.

Radiocarbon dating was done at the ${ }^{14} \mathrm{C}$ dating laboratory, the University of Helsinki, using the methods described in Jungner (1978).

The references for the methods used in determining the degree of decomposition have been given in Tolonen (1982).

Relative pollen analyses were carried out by (conventional) standard method, the number of AP counted ranging from about 100 to 300 , if not otherwise stated. Selected AP taxa are presented as percentages of the AP total; some NAP taxa are given as percentages of AP + NAP taxa.

\section{Results and discussion}

\section{Kevolansuo, Paimio}

The topmost $0-190$ section of the ombrotrophic Sphagnum peat in the middle of 
Kevolansuo bog in Paimio was obtained with a shovel as a continuous monolith from a handdug open peat face (Fig. 2).

The core was analysed for ash and pollen (to a basic sum of 500 AP) every $5 \mathrm{~cm}$ (Mirjami Tolonen's unpublished data). When compared with an adjacent pollen diagram ( $5 \mathrm{~m}$ east of the site) (unpubl.) and with the pollen diagram by Aurola (1938) from the same bog, it is obvious that

1) the lowermost samples represent the stratum a little above the rational limit of spruce (Picea), that is, they originate from about 3300 B.P.

2) the fairly distinct decline in the QM a bit below $1.0 \mathrm{~m}$ may correspond approximately to the regional (S.W. Finland) retrogression of »Quercetum mixtum» around 2500 B.P. or so.

The ombrotrophic Sphagnum peat goes down to about $2.5-3.0 \mathrm{~m}$ at this and adjacent sites.

An interesting natural rise in the ash curve (about $1 \%$ unit) is associated with the macroscopic charcoal layer at $0.85 \mathrm{~m}$. There is, however, no indicative rise (but rather a decline) in the ash content of peat until at $0.65 \mathrm{~m}$, with the onset of field erosion by wind ( $c f$. Vuorela 1983) even though the pollen indicators show an extremely marked increase in agricultural activity and crop cultivation between 1.0 and $0.65 \mathrm{~m}$.

The elevated ash content right at the surface (up to $4.15 \%$ ) will be discussed later.

\section{Kunonniemensuo, Kitee}

The small raised bog, »Kunonniemensuo», is situated in esker terrain in Kunonniemi, Kitee. The total depth of peat at the coring site of the profile (Fig. 3) was $4.3 \mathrm{~m}$, the upper $3.8 \mathrm{~m}$ consisting of ombrotrophic Sphagnum peat. All the peat strata were analyzed for pollen by Jukka Vuorinen (unpubl.), but only the top $1.65 \mathrm{~m}$ of the profile is discussed in the present context.
About 400 AP were counted at each level. The moss-increment (Fig. 3) and the ${ }^{210} \mathrm{~Pb}$ ages (ElDaoushy et al. 1982) are consistent with each other. The radiocarbon ages are in good agreement with the start of rye cultivation dated from the annually laminated sediments of the nearby lake Hännisenlampi (Vuorinen 1978).

The ash content curve parallels that of the pollen indicators of crop cultivation (Secale and other cereals, Rumex acetosella type, etc.). The pollen counting performed by Jukka Vuorinen revealed diverse weed flora, including taxa such as Spergula arvensis (abundantly) and Scleranthus species (to be published later).

The substantial rise in Alnus (and Pteridium) with the simultaneous fall in Picea, may indicate the prevalence of slash-and-burn agriculture in the vicinity.

Be that as it may, the distinct, albeit slight, rise in the ash content of peat (from about $0.8 \%$ to about $1.4 \%$ ) starting concurrently with the appearance of rye and other pollen is apparently associated with the wind erosion of cultivated soils in the vicinity. The same factor may well be reflected in the isothermal remanent magnetization figures at the Kunonniemi sites, where they increased earlier than in other dated peat profiles from Finland (Oldfield et al. 1979).

Another distinct rise in the ash (up to $2.3 \%$ ) occurs in the top $15 \mathrm{~cm}$, which corresponds to about the last 20 years. There is no corresponding rise in the culture indicators at that time, which is natural because there has been a regeneration of pine forest since slash-and-burn cultivation ceased there some $70-80$ years ago (dated by the age of local pine stand) and the practice of using forest as pasture came to an end three decades or so ago.

It seems likely therefore that the final rise in the ash curve is most likely due to the natural "surface enrichment» of certain nutrients, such as $\mathrm{K}, \mathrm{Na}, \mathrm{Ca}, \mathrm{Mn}, \mathrm{Al}, \mathrm{Si}$ and $\mathrm{P}$ in living vegetation. The topic will be discussed in details later. 
KUNONNIEMENSUO, KITEE

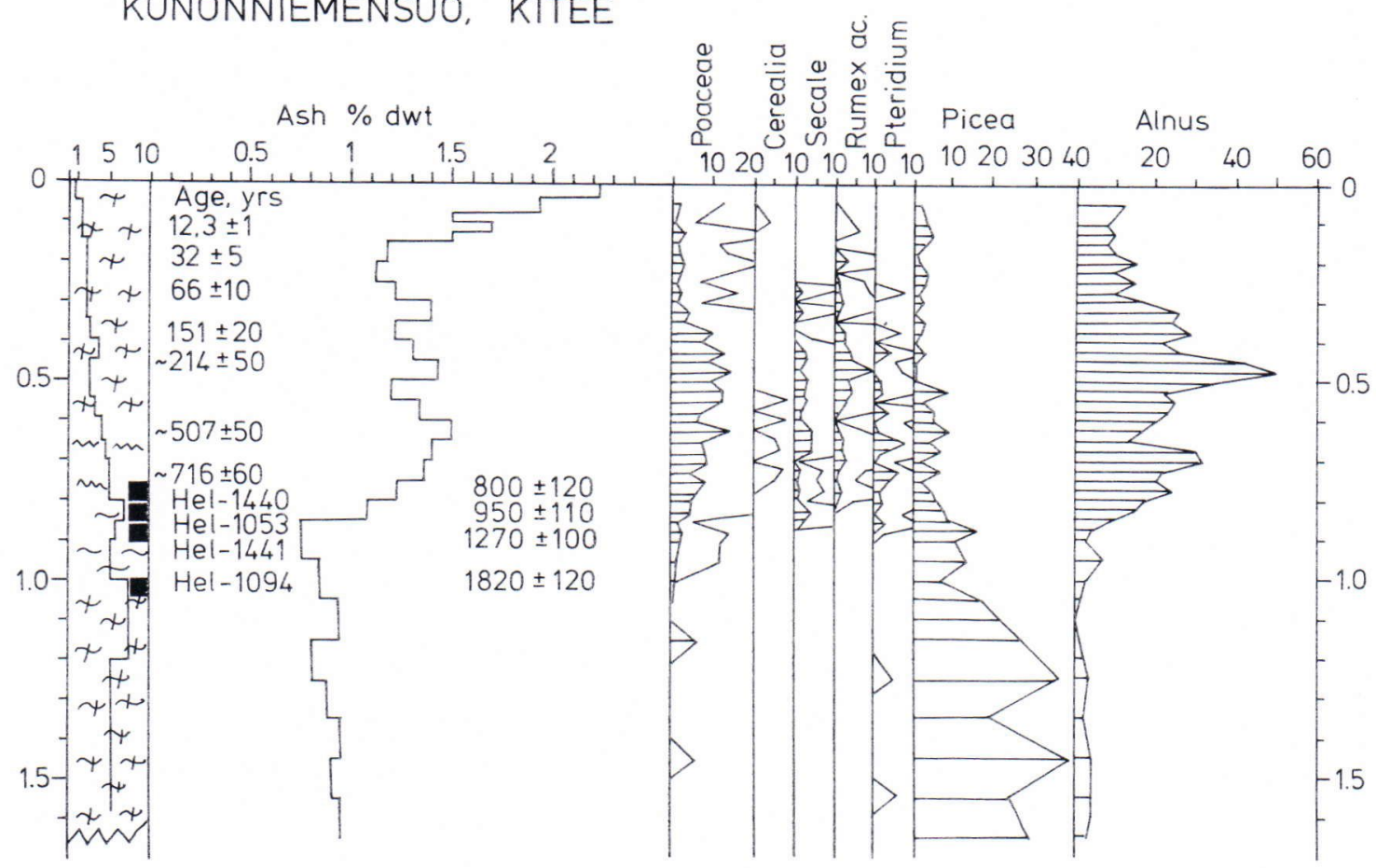

Fig. 3. Raised bog Kunonniemensuo, Kitee 1976. Ash content of peat compared with the humification of peat (cf. Fig. 2) and selected indicators of cultivation and slash-and-burn agriculture as occurring in pollen analysis.

Ages younger than 800 B.P. by means of moss-increment dating revealed as for 5 B (see Fig. 5). For other explanations, see Figs. 1 and 2. Pollen analyses by Jukka Vuorinen (unpubl.).

- The water table lies at about $30-35 \mathrm{~cm}$ from the surface.

The role of anthropogenic soot is not excluded, but it could hardly cause as strong a rise as that observed here.

\section{Linnasuo, Tuupovaara}

The hummock core (Fig. 4) was obtained from a 40-cm-high Sphagnum fuscum hummock (Fig. 2 in Tolonen 1966), and the hollow profile from a wet Scheuchzeria - Sphagnum majus surface $2 \mathrm{~m}$ west of it. The microscopic peat analyses and pollen diagrams for every $5 \mathrm{~cm}$ from the hummock core have been published earlier (Tolonen 1966, 1967) as have the ash, $\mathrm{CaO}$ and $\mathrm{MgO}$ content curves (every 5 or $10 \mathrm{~cm}$ ). In 1976 a new core was obtained from exactly the same site as the earlier hummock core, but the new one was sliced in the field into vertical sections as homogeneous as possible in terms of the degree of decomposition. Because of this difference in slicing, the older and newer ash content curves are not the same, although they are very similar.

The pollen analysis (Tolonen 1967, p. 289) shows that there is a clear rise in the Poaceae curve at $0.55 \mathrm{~m}$ and continuous Rumex acetosella starting at $0.5 \mathrm{~m}$, but that the only Cerealia type encountered does not start until $0.25 \mathrm{~m}$. There was a clear decline in Picea concurrently with increasing Poaceae. All these features imply that agricultural activity started in the vicinity at a time corresponding to a depth of about $0.5 \mathrm{~m}$ in the hummock core. Radiocarbon dating is available from $0.95-1.00 \mathrm{~m}: 1350 \pm$ 


\section{LINNASUO, TUUPOVAARA}

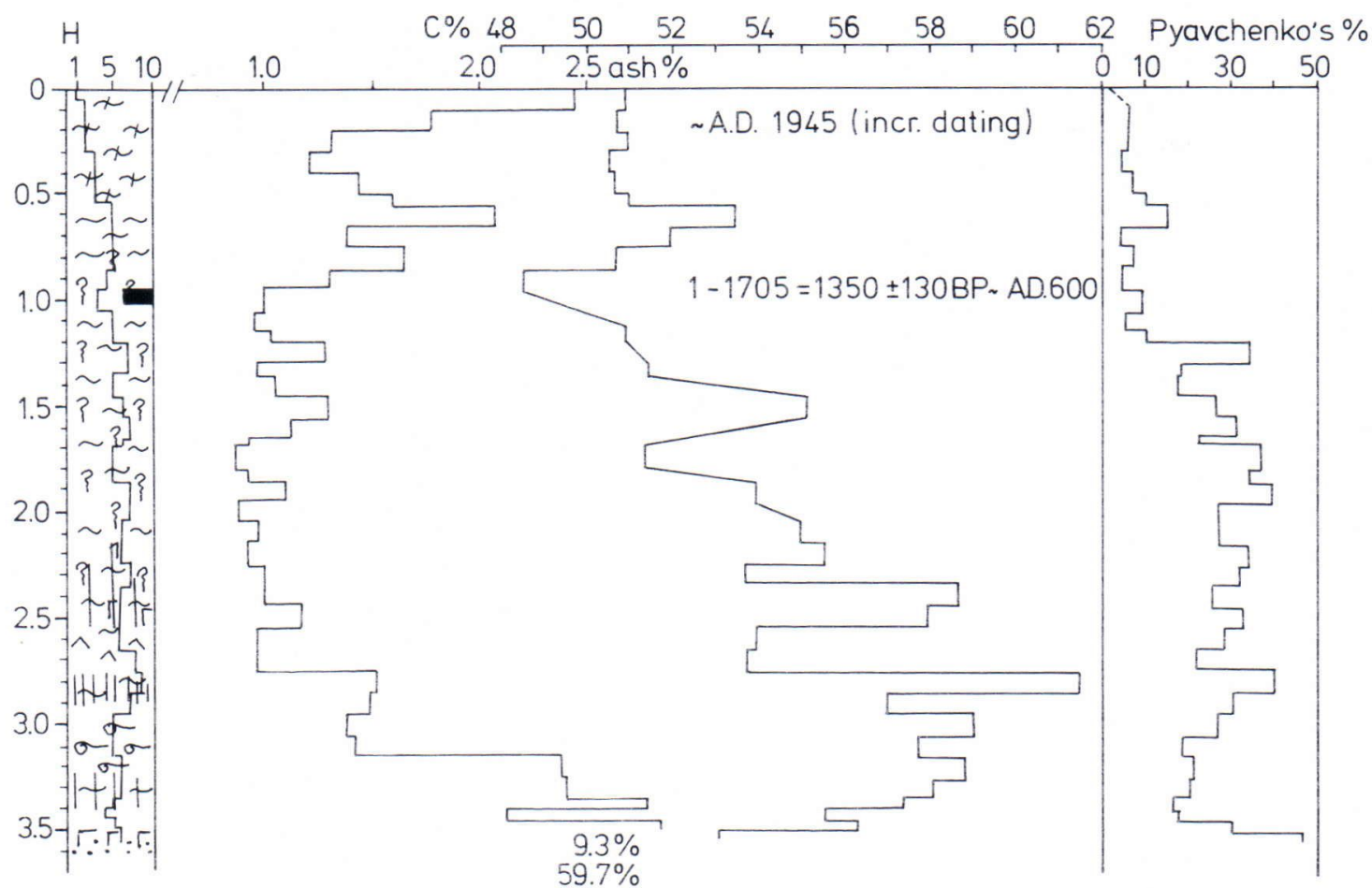

Fig. 4. Raised bog Linnasuo, Tuupovaara, 1976. Ash content compared with some physical properties of peat. For explanations, see Figs 1 and 2.

130 B.P., but this is little help in dating the 0.5 $\mathrm{m}$ level. Moss-increment counting indicates that the $0.20 \mathrm{~cm}$ level is about 30 years old.

The ash content curve, and in several cases the carbon content as well, exhibits several small but clear peaks between 0 and $2.0 \mathrm{~m}$ that coincide with the elevated figures obtained for peat humification. Unfortunately, carbon analyses were nor available for every $10 \mathrm{~cm}$ between 1.0 and $2.0 \mathrm{~m}$. It is unlikely therefore that the ash content curve for Linnasuo has good indicator value in tracing the history of agriculture in the area, all the more so because of the dearth of historical records of settlement in the area before A.D. 1500.

The final rise in the ash curve at the top of the profile about 30 years ago is certainly mainly due to »biological» factors and will be discussed later.

The hollow profile ( $2.0 \mathrm{~m}$ apart) does not exhibit any rise in the ash content within the uppermost $0.2 \mathrm{~m}$ but a drastic decline from 2.75 $-2.95 \%$ at $0.60-0.33 \mathrm{~m}$ to about $1.7 \%$ at $0-0.22 \mathrm{~m}$; from 0.6 to $2.0 \mathrm{~m}$ the ash content varies from 0.7 to $1.1 \%$ (mean about $0.9 \%$ ). The hollow core is easily connected with the hummock core using exactly the same fluctuations in the humification figures from $1.0 \mathrm{~m}$ downwards. The ash content curve parallels the curves for peat humification made by four different methods (v. Post, unrubbed fibre, centrifuge and Pyavchenko). It is plausible that the peak value of the ash content in this hollow profile (c. $3 \%$ at $0.33 \mathrm{~m}$ ) is largely due to enrich- 
ment of Rhynchospora alba remains in that zone. In an analysis by Sjörs \& Malmer (1955) the ash content in a shoot of Rhynchospora alba ranged from 2.2 to $4.5 \%$, whereas the roots had 3.3-9.5\% ash (the corresponding $\mathrm{SiO}_{2}$ content varied from 0.9 to $2.5 \%$, and the Fe content from 0.004 to $1.0 \%$ ).

\section{Munasuo, Pyhtää}

Figure 5 (A) compares the ash content curve of a hummock core (dated by three independent methods) with pollen curves of cereals and Rumex acetosa/acetosella (unpubl.), as well as with the humification curve (v. Post's method).

There is a significant contemporaneous rise in the ash and culture indicator curves at about 200 years ago, whereas the earliest Cerealia occurrences dated at $420 \pm 160$ B.P. cannot be traced through the variation in ash content. Unlike the slight possible correlation between ash content and humification below $0.5 \mathrm{~m}$, the subsurface increase in ash content cannot be explained by the humification; rather it is caused by airborne dust from fields etc. The ash content in the top $5 \mathrm{~cm}$ reaches $3.85 \%$, probably largely for natural, biological reasons, to be discussed later.

\section{Kärpänsuo, Kuhmoinen}

A significant but stepwise rise in the ash curve of this core (Fig. 5 B) occurs in layers representing the past 50 years. The ash content in peat dating from less than 10 years back has more than doubled (from 2.0 to $4.8 \%$ ). During this period the owners of the nearby Kirvesmäki farm (the only one in the vicinity) have been forced by old age to cease cultivating their fields. Therefore the final rise in the ash can hardly be explained by the anthropogenic factor, which may well be one of the possible reasons for the elevated ash content in the early years of this century, because the degree of decomposition is constant or even decreasing. The proportion of vascular plant remains (see
Pakarinen \& Tolonen 1977, Fig. 2), however, strongly correlated with the ash content in the topmost $0.5 \mathrm{~m}$ of this core. For lack of pollen data and detailed analyses of the ash it is not possible to assess the role of airborne pedogenic particles at Kärpänsuo.

\section{Liikasenvaara, Kuusamo}

The two cores (Fig. 5 C, D) are from adjacent hummocks from a small ombrotrophic $S$. fuscum mire. The ash content was only analysed in the top 0.5 and $0.35 \mathrm{~m}$ sections dating back to about 150 years in core 1 . There was a slight but probably insignificant rise in the ash content at about $30-40$ years ago; the real rise on the top corresponds to about the last 15 years. There has been permanent settlement and cultivation at Liikasenvaara for several centuries, but during the past two decades there has been a strong trend towards depopulation and cessation of farming in the area.

\section{Ahvenjärvenvuoma, Kittilä}

The core (Fig. 5 E) was obtained from the same site as that for the pollen diagram and microscopic peat analysis in Ruuhijärvi (1963). The top $20 \mathrm{~cm}$ were dated by the moss-increment method and the lower part (below $0.5 \mathrm{~m}$ ) by radiocarbon methods. The pollen study gives no clear indications of agriculture but the ash curve exhibits two pronounced peaks (1.35$1.4 \mathrm{~m}$ and $0.0-0.15 \mathrm{~m}$ ). The earliest peak and, except for the top $15 \mathrm{~cm}$, the general trend in the ash curve parallel that for peat humification. In the light of these data and the results of dating the ash content variation in this core is probably a poor reflection of the historically known agricultural development (and decline) in the area.

\section{Jänkävuopajanaapa, Sodankylä}

The ombrotrophic peat layer of this site (Fig. $5 \mathrm{~F}$ ) consists of the top $0.5 \mathrm{~m}$ only. This fact is 

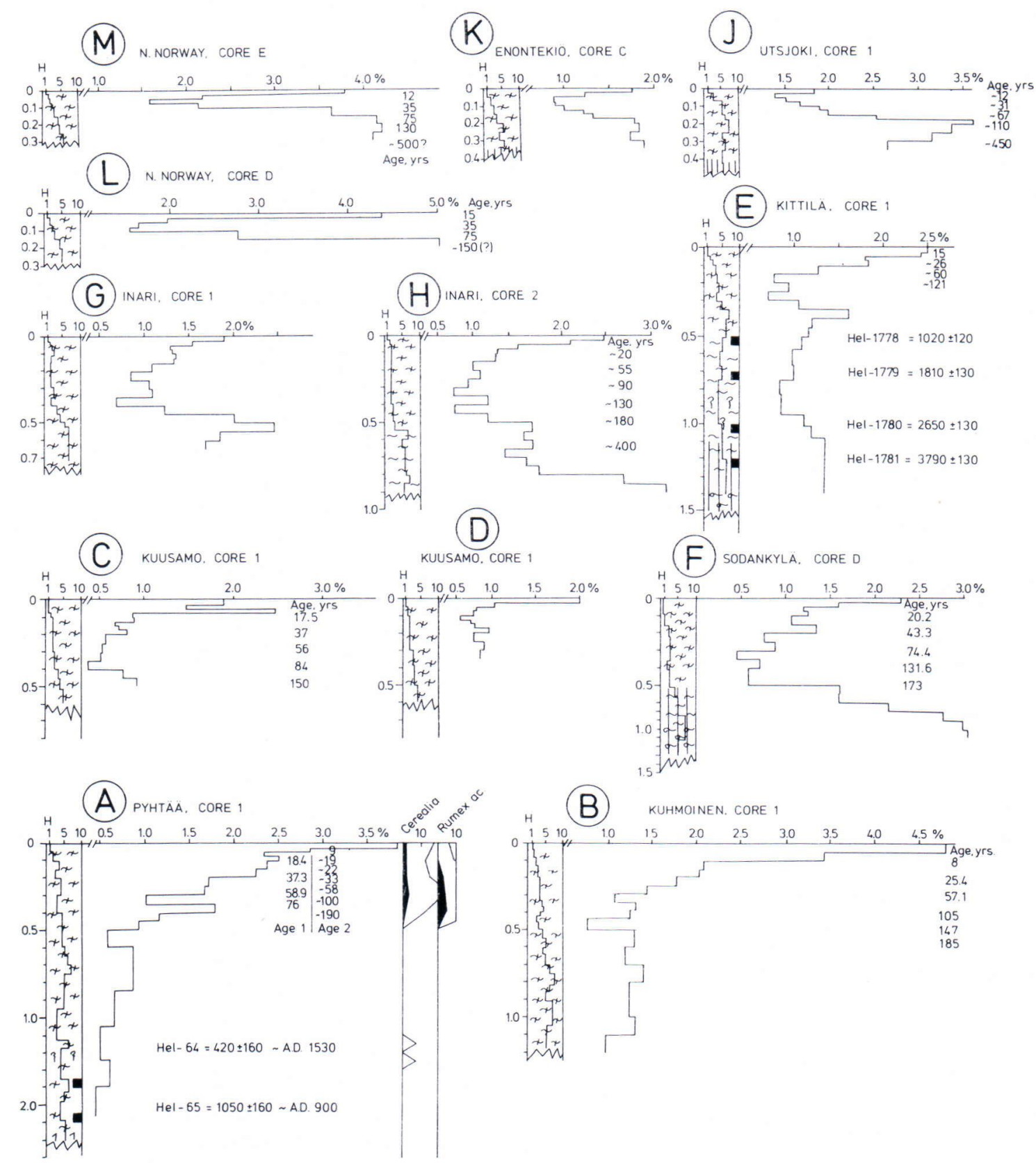

Fig. 5. Ash content curves for ten dated peat cores from Finland and two from N. Norway (cf. Table 1), collected in 19751977. The subsurface peat dated by moss-increment method (in $5 \mathrm{~A}$ also by ${ }^{210} \mathrm{~Pb}$, using c.r.s. model: Age 2). In $5 \mathrm{~B}$ the moss-increment dating was in good agreement with ${ }^{210} \mathrm{~Pb}$ dating (El-Daoushy et al. 1982). The statistical error in the both methods are omitted. In the moss-increment-method it ranges from 10 to $30 \%$ (one S.D.). Ages greater than 130 yrs (using the moss-increment method) are based on the assumption that the peat accumulation percentage (see Tolonen 1979) has reached a constant level. For other explanations, see Figs 1 and 2 and the text. 
clearly reflected in the ash content, which at $1.0 \mathrm{~m}$ is over $3.0 \%$, but in the ombrotrophic Sphagnum peat as low as $0.5 \%$.

The ash content has risen stepwise towards the surface during the past 40 years or so (mossincrement dating). According to my field observations in 1974 and 1976, the mixed forest in the vicinity (Picea, Pinus \& Betula) was most probably used for slash-and-burn cultivation, but this activity did not continue into the present century. Consequently, the subsurface rise in the ash content is not likely to be an indicator of land use in the area.

\section{Ahmajänkä, Inari}

The two cores from this northern raised bog (Fig. 5 G, H) were taken on Dr. R. Ruuhijärvi's instructions from close to the site from which a core was taken earlier for pollen and detailed peat analysis (Ruuhijärvi 1963). The ash contents are dealt with in this context only for the top $0.9 \mathrm{~m}$ and $0.65 \mathrm{~m}$ sections, because the deeper peat was so highly decomposed that its ombrotrophic nature remained unsolved. Deeper in the profiles the ash curves follow those of humification, but the surface maximum (corresponding to less than the 50 last years) has no connection with humification. All the pollen flora, except one Artemisia pollen grain at 0.1 $\mathrm{m}$, exhibit culture indicators. The nearest farm is more than $\mathrm{km}$ away.

\section{Skallovarri, Utsjoki, Peerajärvi, Enontekiö and two peat cores from northern Norway}

While the precious site (Ahmajänkä) was from the northern pine zone, these four profiles (Fig. $5 \mathrm{~J}-\mathrm{M}$ ) are from the subalpine birch zone, although the Norwegian site is very close to treeless tundra. The profiles are all from the top Sphagnum fuscum layer of big, permanently frozen hummocks on palsa mires. The sites lack tree cover. The vertical distributions of ash in the four cores are very similar: a distinct peak in the top $2.5-5 \mathrm{~cm}$, the minimum just under this and a strong rise downwards compatible with the increase in the degree of peat decomposition.

\section{Additional sites}

Data on the detailed vertical distribution of ash content, subfossil pollen grains and peat humification (measured with several different methods and a total of ten stratigraphically consistent radiocarbon datings within the top $3.0 \mathrm{~m}$, Tolonen 1979, Jungner 1979, 1983) are available from Punassuo, Perniö and Laaviosuo, Lammi.

To save space the diagrams will be published in another paper.

Results from both sites revealed a general rise in the ash content from about $0.5 \%$ to $2.5 \%$ within the top $0.7 \mathrm{~m}$ at Punassuo and $1.5 \mathrm{~m}$ at Laaviosuo.

At Punassuo there was a delay of 500 years or more (?) before the ash curve began to rise after the first occurrence of agricultural activity (after A.D. $930 \pm 120$ ). In the more recent layer the ash and cereal curves are consistent with one another.

In Laaviosuo, too, the earliest traces of clearance and slash-and-burn culture (an abrupt drop in Picea and the first cereals, etc. about A.D. 400) cannot be traced in the ash curve of peat. On the contrary, by about A.D. 900, the ash and cereal curves rise and fall coincidently, but the spruce curves reciprocally. What is more, except in some levels, the big fluctuations in peat humification are closely correlated to the ash curve within the same section. Nowadays the peatland is surrounded by dense spruce forests, and correspondingly the share of Picea pollen in the top sample is $35 \%$. Therefore the final two-fold rise of ash content in the top $2.5 \mathrm{~m}$ (covering the past few years) has some other cause than agricultural dust.

\section{Discussion}

As in numerous earlier studies, the present material indicates that the ash content of om- 
brotrophic peat depends on several factors, one of which is peat humification ( $c f$. Salmi 1947, 1954 Mattson \& Koutler-Andersson 1954, Lappalainen 1970, Päivänen 1973, p. 36). Taking all the peat types of the samples $(n=534)$ gathered by the author from Finnish peatlands into consideration the ash content has highly significant $(\mathrm{p}<0.001)$ linear correlations with the peat humification measured by five different methods, linear $r$ ranging from 0.295 to 0.445 , and with the carbon content of peat ( $\mathrm{r}=$ $0.457, \mathrm{p}<0.001$ ). The carbon content of peat is naturally one of the best measures of peat humification.

There are at least four alternative explanations for the elevated ash content in highly decomposed peat: first, the more effective the disintegration of organic matter, the greater is the enrichment of inorganics in the peat itself (primary ash). Second, the more decomposed the peat, the slower is its rate of growth (Tolonen 1979), with the consequence that the peat surface is long exposed to the atmospheric input of different incombustible particulates (secondary ash). It derives from at least five different sources as thoroughly discussed by Mattson \& Koutler-Andersson (1954). Third, regarding Sphagnum mires in particular, certain plant species which selectively accumulate some metals readily colonise or multiply on more decomposed surfaces (e.g. dwarf shrubs) that are enriched in Mn etc. (up to five $\%$ of dry weight, Damman 1978, p. 487, Pakarinen 1981). Furthermore, the improved nutrition associated with a more decomposed peat surface results in better growth of forest stand (if trees grow in the area) and therefore in an increased removal of certain metals to the peat from the canopy by rain (Päivänen 1974).

The large material gathered by Davis et al. (1980) from the thick Sphagnum peat deposits of Maine, USA shows a very strong positive correlation between the ash content and the calorific value of peat. In »pure» Sphagnum peat, however, the correlations is often fairly low or even reversed (Mäkilä 1980) when the surface peats are included. Subsurface and surface peat commonly contain more ash than the deeper stratum of the same peat type (even though it is generally more decomposed).

Several scientists have paid attention to this surface enrichment of ash since the study of $\mathrm{v}$. Post (1925). In most of the studies the role of air-borne mineral particles from arable land has been emphasized, but it was Chapman (1964) who definitely proved it. He distinguished between opaline biogenic silica (from plant phytolites etc.) and mineral quartz particles in peat by means of their different refractive indexes. A close relationship existed between the ash (and $\mathrm{SiO}_{2}+\mathrm{Al}_{2} \mathrm{O}_{3}$ ) content of subsurface Sphagnum peat and the occurrence of pollen grains characterizing agriculture and bare mineral soils in Chapman's (1964) diagrams. Therefore he subscribed the rising ash curve to the windblown dust from cultivation, as did Assarsson (1961) and many others.

This theory is apparently valid in interpreting the vertical ash curve of some of the sites presented above (Kunonniemensuo, Kitee, in particular), even if definite proofs are few. The gradually diminishing ash content in the topmost virtually »clean» Sphagnum fuscum (free of local contaminants and vascular plant remains) is visible in the present material on sites from southern Finland to Finnish Lapland. This regionality supports the concept that the chief impact on the ash content of Sphagnum fuscum is »field erosion by wind» (Vuorela 1983) from cultivated soils (see also Gorham \& Tilton 1978). The mineral dust from roads can be excluded as an alternative explanation because the sampling sites are more than $250 \mathrm{~m}$ from the nearest roads (Salmi 1969).

North of the forest limit in Norwegian Lapland the ash content of similar surface peat material rises once more. As cultivated areas are small, scantly and located far from the coring site (Table 1), the surface ash at high latitudes obviously does not originate from arable land; 
instead it derives from wind-blown mineral matter from treeless or semi-open fell heaths and, partly, from oceanic salt spray blown by heavy storms ( $c f$. Sonesson 1970).

The value of ombrotrophic Sphagnum peat in tracing the history of cultivation has been suggested by Vuorela (1983). It is complicated, however, by the variation in ash content accompanying the variation in peat decomposition discussed above, and still further by the mineral salt uptake of living mire plants and various other features of the mobility of elements in subsurface and surface peat.

During the past few years factors involved in the recycling, leaching and other processes in peat have been studied by several authors including Sillanpää (1972), Moore \& Bellamy (1973), Rump et al. (1977), Damman (1978), Yamagata (1982) and Pakarinen et al. (1983 with references). Some elements (K, Ca, Mn, P and $\mathrm{B}$ ) tend to concentrate in the living parts of plants by active uptake and other mechanisms, whereas others ( $\mathrm{Fe}$ and $\mathrm{Al}$ ) exhibit marked enrichment horizons in the subsurface (usually between 20 and $35 \mathrm{~cm}$ ). The distribution of these elements in the peat cores of the present study follows the pattern given above for $\mathrm{Mu}$ nasuo, Kärpänsuo, Laaviosuo, and Ahmajänkä (Pakarinen 1978, Pakarinen \& Tolonen 1977 b, 1983, Oldfield et al. 1981) and for Ahvenjärvenvuoma (unpubl.).

Our understanding of the geochemistry of Sphagnum peat (including the mobility of elements) is enhanced by the radiochemical analyses. In the well-dated Kärpänsuo core (ElDaoushy et al. 1982) (Fig. 5 B), for instance, the vertical distribution of ${ }^{137} \mathrm{Cs}$ does not follow the known temporal fall-out pattern of this fission product but the vertical curve of potassium, the two elements exhibiting an exponential rise during the last ten years (Pakarinen \& Tolonen $1977 \mathrm{a})$. In the same core another nuclear bomb isotope ${ }^{239,240} \mathrm{Pu}$ has been leached downwards, being strongly enriched in layers below $35 \mathrm{~cm}$, corresponding to the time before the Second World War (T. Jaakkola \& K. Tolonen unpubl.). Sakanoue \& Komura (1982) reported similar findings from a raised bog in Japan.

Analysing the lead isotopes ${ }^{204} \mathrm{~Pb},{ }^{206} \mathrm{~Pb}$, ${ }^{207} \mathrm{~Pb}$ and ${ }^{208} \mathrm{~Pb}$ in snow, bedrock and a Sphagnum core covering 8000 years, Murozumi \& Nakamara (1982) were able to show that the lead of the peat deposits during the ombrotrophic period mentioned does not originate from the bedrock but solely from atmospheric dust.

Results like these, of course, are extremely valuable in geochemical prospecting for ores, because they demonstrate that only peat types other than the Sphagnum peat of raised bogs can be applied ( $c f$. Salmi 1955, Yliruokanen 1976). The isotope geochemical studies mentioned also indicated, however, that both the role of erosion by wind of cultivated soils as the sole factor causing the surface ash maximum in raised bogs as claimed by Mattson \& KoutlerAndersson (1954) and the »element-lifting activity» of plants as the explanation for the same feature as presented by Sillanpää (1972) are only partly right.

Hence, although an autochtonous formation, ombrotrophic peat has appeared to a heterogeneous matrix and a poor recorder of temporal changes in land use.

In lake sediments, which are chiefly from allochtonous sources, simple ash content analyses and traditional lithophilic elements such as K, Na, Ma, Ca and Fe (Mackereth 1965, Lavac et al. 1978) have worked well as indicators of field erosion (e.g. Tolonen et al. 1975, Tolonen 1980).

Ash content may provide valuable information about the wind-blown dust in peat, too, but its unambiguous interpretation requires careful examination and detailed analysis.

Acknowledgements. My sincere thanks are due to $\mathrm{Mr}$. Jukka Vuorinen and Dr. Mirjami Tolonen for their kindness in providing me with unpublished pollen diagrams and other material and to Ms. Pirkko Dookie for her technical assistance. 


\section{References}

Assarsson, G., 1961. Södra Sveriges torvtillgångar. II. Kemiska analyser. (The supply of peat in southern Sweden. II. Chemical analyses.) Sveriges Geol. Undersökn. Ser. C. 578, 1-25.

Aurola, E., 1938. Die postglaziale Entwicklung des südwestlichen Finnlands. Bull. Comm. Géol. Finl. 121, $1-166$.

Chapman, S. B., 1964. The ecology of Coom Rigg Moss, Northumberland II. The chemistry of peat profiles and the development of the bog system. Journ. Ecol. 52, $315-321$.

Damman, A. W. H., 1978. Distribution and movements of elements in ombrotrophic peat bogs. Oikos 30, 480495.

Davis, J.; Anderson, W. \& Cameron, C., 1980. Peat resource evaluation. State of Maine. Peat Programme. Final report; phase one July 1980, 17 pp +7 Tables. U.S. Dept. of Energy, Office of Fossil Energy.

El-Daoushy, F.; Tolonen, K. \& Rosenberg, R., 1982. Lead 210 and moss-increment dating of two Finnish Sphagnum hummocks. Nature 296, 429-431.

Gorham, E. \& Tilton, D., 1978. The mineral content of Sphagnum fuscum as affected by human settlement. Can. I. Bot. 56, 2755-2759

Jungner, H., 1979. Radiocarbon dates I. Radiocarbon Dating Laboratory, University of Helsinki. Report 1, $1-131$.

Jungner, H. \& Sonninen, E., 1983. Radiocarbon Dates II. Radiocarbon Dating Laboratory, University of Helsinki. Report 2, 1-121.

Lavacz, W., Planter, M., Stasiak, K., Tatur, A. \& Wiekowski, K., 1978. The past, present and future of three Mazurian lakes. Pol. Arch. Hydrobiol. 25, 233238.

Mackereth, F. J. H., 1965. Chemical investigation of lake sediments and their interpretation. Proc. R. Soc. B. 161, 295-309.

Mattson, S. \& Koutler-Andersson, E., 1954. Geochemistry of a raised bog. Kungl. Lantbrukshögsk. Ann. 21, 321 -366 .

Mäkilä, M., 1980. Toholammin turvevarojen käyttökelpoisuus ja turpeen ominaisuuksien välinen riippuvuus (The peat resources of Toholampi municipality and their potential use and correlation between peat properties.) Geol. tutkimuslait. maaperäosasto. Raportti P 13, 4/80/5, 1- 149 .

Mörnsjö, T., 1968. Stratigraphical and chemical studies on two peatlands in Scania, South Sweden. Bot. Notiser $121,343-360$.

Malmer, N. \& Sjörs, H., 1955. Some determinations of elementary constituents in mire plants and peat. Bot. Notiser 108 (1), 46-80.
Murozumi, M. \& Nakamara, S., 1982. The isotopic abundance of lead in the Ozegahara Moor. 119-122 in, Hara, Hiroshi (ed.), Ozegahara: Scientific Research of the Highmoor in Central Japan. Japan Society for the Promotion of Science. Tokyo.

Oldfield, F.; Tolonen, K. \& Thompson, R., 1981. History of particulate pollution from magnetic measurements in dated Finnish peat profiles. Ambio 10, 185-188.

Päivänen, J., 1973. Hydraulic conductivity and water retention in peat soils. Acta Forest. Fenn. 129, 1-70.

Päivänen, J., 1974. Nutrient removal from Scots pine canopy on drained peatland by rain. Acta Forest Fenn. $139,1-19$.

Pakarinen, P., 1978. Distribution of heavy metals in the Sphagnum layer of bog hummocks and hollows. Ann. Bot. Fennici 15, 287-292.

Pakarinen, P., 1981. Metal content of ombrotrophic Sphagnum mosses in NW Europe. Ann. Bot. Fennici $18,281-292$.

Pakarinen, P. \& Tolonen, K., 1977 a. Pintaturpeen kasvunopeudesta ja ajoittamisesta. (On the growth-rate and dating of surface peat.) Suo 28, 19-24.

Pakarinen, P. \& Tolonen, K., 1977 b. Pääravinteiden sekä sinkin ja lyijyn vertikaalijakautumista rahkaturpeessa. (Vertical distributions of $\mathrm{N}, \mathrm{P}, \mathrm{K}, \mathrm{Zn}$ and $\mathrm{Pb}$ in sphagnum peat.) Suo 28, 95-102.

Pakarinen, P.; Tolonen, K.; Heikkinen, S. \& Nurmi, A., 1983. Accumulation of metals in Finnish raised bogs. 377-382 in Hallberg, R. (ed.), Environmental Biogeochemistry, Ecol. Bull. (Stockholm) 35.

Post, L.v., 1925. Einige Aufgaben der regionalen Moorforschung. Sveriges Geol. Undersökn. Ser. C. 337, $1-41$.

Rump, H. H.; Werden, K. van \& Herrmann, R., 1977. Ueber die vertikale Änderungen von Metallkonzentrationen in einem Hochmoor. Catena 4, 149-164.

Ruuhijärvi, R., 1963. Zur Entwicklungsgeschichte der nordfinnischen Hochmoore. Ann. Bot. Soc. 'Vanamo' 34 (2), $1-42$.

Sakanoue, M. \& Komura, K., 1982. Depth profiles of ${ }^{210} \mathrm{~Pb},{ }^{137} \mathrm{Cs}$ and ${ }^{238},{ }^{240} \mathrm{Pu}$ in Ozegahara core samples. 109-117 in Hara, Hiroshi (ed.), Ozegahara, Scientific Research of the Highmoor in Central Japan. Japan Society for the Promotion of Science. Tokyo.

Salmi, M., 1947. Turpeiden tuhkapitoisuukista ja lämpöarvoista. (The heat value and percentage of ash in peat). Tekn. Aikak. lehti 4, 151-153.

Salmi, M., 1954. Investigation of the calorific values of peats in Finland. 1st Int. Peat Congress, Dublin, Ireland, July 1954, Section B3, 9 pp.

Salmi, M., 1955. Prospecting for bog-covered ore by means of peat investigations. Bull. Comm. Géol. Finl. 169, $1-34$.

Salmi, M.. 1967. Peat in prospecting: applications in 
Finland, 113-126, in Kvalheim, A. (ed.), Geochemical prospecting in Fennoscandia.

Salmi, M., 1969. Tienvarsien saastuminen Suomessa. (Contamination of roadsides in Finland.) Terra 81, 229233.

Salonen, K., 1979. A versatile method for the rapid and accurate determination of carbon by high temperature combustion. Limnol. Oceanogr. 24, 177-183.

Schneekloth, H., 1963. Beiträge zur Kenntnis niedersächsischer Torflagerstätten. Beih. geol Jahrb. 55, 1-138.

Sonesson, M., 1970. Studies in mire vegetation in the Torneträsk area, northern Sweden. Bot. Not. 123, 67111.

Sillanpää, M., 1972. Distribution of trace elements in peat profiles. Proc. 4th Int. Peat Congr. Finland 1972, Vol 5, 185-191.

Sylvester, T. W. \& Wein, R. W., 1971. Fuel characteristic of arctic plant species and simulated plant community flammability by Rothermel's model. Canadian J. Bot. 59, 898-907.

Tallis, J. H., 1963. The terrestrialization of lake basins in North Cheshire with special reference to the development of »Schwingmoor» structure. Journ. Ecol. 61, $537-567$.

Tolonen, K., 1966. Soiden kehityshistorian tutkimusmenetelmistä. (On methods used in studies of the peatland development.) Suo 17, 93-102.

Tolonen, K., 1967. Ueber die Entwicklung der Moore im finnischen Nordkarelien. Ann. Bot. Fennici 4, 219-416 +6 App.
Tolonen, K., 1982. Usefulness of five common methods of determining the degree of decomposition in estimating the amount and energy content of fuel peat in Finland. Suo 33, 133-142.

Tolonen, K. \& Saarenmaa, L., 1979. The relationship of bulk density to three different measures of the degree of peat humification. Proc. Int. Symp. Classification of Peat and Peatlands, Hyytiälä, Finland. International Peat Society. Helsinki, 227-238.

Tolonen, K., Siiriäinen, A. \& Thompson, R., 1975. Prehistoric field erosion sediment in Lake Lojärvi, S. Finland and its palaeomagnetic dating. Ann. Bot. Fennici $12,161-164$.

Tolonen, K. \& Ijäs, L., 1982. Comparison of two peat samplers used in estimation of dry peat yield in field inventories. Suo 33, 33-42.

Vuorela, I., 1983. Field erosion by wind as indicated by fluctuations in the ash content of Sphagnum peat. Bull. Geol. Soc. Finland 55, 25-33.

Yamagata, N., 1982. Biogeochemical studies on the Ozegahara Moor. 91-107 in Hara, Hiroshi (ed.), Ozegahara, Scientific Research of the Highmoor in Central Japan. Japan Society for the Promotion of Science. Tokyo.

Yliruokanen, I., 1976. Heavy metal distribution and their significance in Finnish peat bogs. Proc. 5th Int. Peat Congress (Poznan, Poland), Vol. 2, 276-283.

Manuscript received, January 14, 1984. 